\title{
Assessing Impact of AMD on Water Quality of the Witwatersrand Basin, Western Basin
}

\section{Khanyiso Nkumanda*}

Department of Water and Sanitation, Zwamadaka Building, Directorate: Compliance Monitoring and Enforcement, South Africa

*Corresponding Author: Khanyiso Nkumanda, Department of Water and Sanitation, Zwamadaka Building, Directorate: Compliance Monitoring and Enforcement, South Africa.

Received: July 22, 2019; Published: September 16, 2019

DOI: $10.31080 / A S A G .2019 .03 .0648$

\begin{abstract}
The main aim of the study was to assess the groundwater and surface water quality of a river system which is affected by Acid Mine Drainage (AMD) issuing from a gold mine on the West Rand in Gauteng, South Africa. The analysis was done during the dry season (August to September 2015) and the wet season (January 2016). Six sampling sites on the Tweelopiespruit, Rietspruit and Bloubankspruit (TRB) were selected for groundwater and surface water analyses. The ICP - OES analyses of the water samples were done by the Waterlab in Pretoria. The $\mathrm{pH}$, sulphates and the metal concentration in the TRB river system which is affected by AMD issuing from Harmony Gold Mine were analysed. The water quality data as per dry and rainy season and source (surface water and groundwater) was then correlated to the Target Water Quality Range (TWQR) as determined by the Department of Water and Sanitation (DWS) to better understand the environmental dynamics the aquatic ecosystem experiences during the study period. A number of remediation measures to address AMD were recommended to mitigate the impacts on the TRB river system. The study was able to acquire knowledge on the impact of gold mining activities on groundwater and surface water quality on the dolomitic aquifer on the West Rand.
\end{abstract}

Keywords: Acid Mine Drainage; Mine Water Management; ICP-OES Analyses; Surface And Groundwater

\section{Introduction}

Water quantity and quality have always played an important role in determining the quality of life for living things. Water quality may be correlated with water use and the state of economic development in a particular country [1]. Both groundwater and surface water may be contaminated in a number of ways. In mining areas Acid Mine Drainage (AMD) and in industrial areas industrial waste contribute significantly to the low quality of water resources [2]. Water resources in most developing countries are located at the receiving end points of effluents discharged from industries and mining areas.

In the Republic of South Africa most water resources are already optimally utilised and are under pressure from the projected growing population rates and social-economic expectations. With the current socio-economic climate and the growing population it is unlikely that the water resources in the Republic of South Africa will be sustainable [3].

\section{Study area}

The study research was conducted at the Western Basin, within the Witwatersrand Basin (more specifically, the West Rand Region) to assess the effects of AMD on the natural environment at the Tweelopiesspruit, Rietspruit and Bloubankspruit (TRB System). The West Rand geology is mainly underlain by dolomitic rocks.

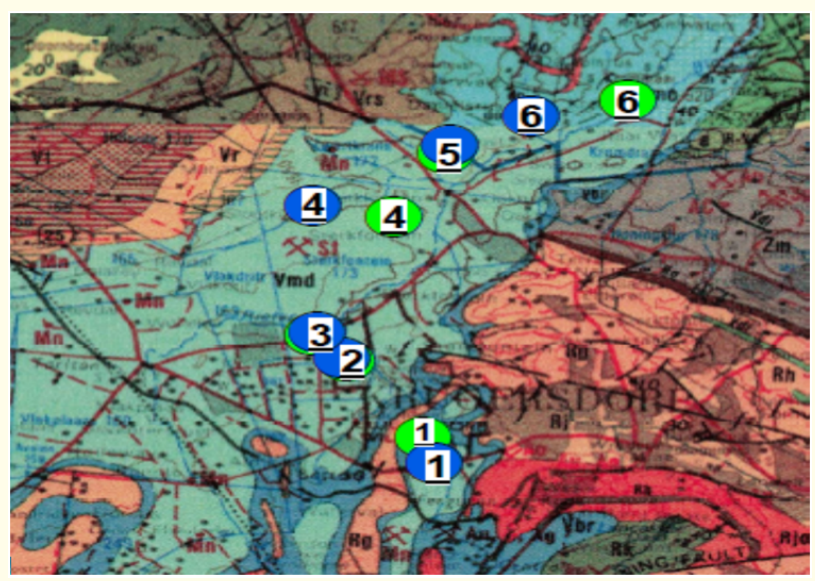

Figure 1: Illustrating sampling sites in West Rand (Green dot-Surface water and Blue dot- Groundwater) (Geological Survey, 1981; Geological Survey 1986)).

The rocks of the Witwatersrand Supergroup and Black Reef Formation are not considered to contain economic and sustainable aquifers. Localised high - yielding boreholes may, however, exist where fractures intersect. Groundwater occurrences are mainly restricted to the weathered formations, although fracturing in the underlying "fresh" bedrock may also contain water. Experience has shown that these open fractures seldom occur deeper than $60 \mathrm{~m}$. The base of the aquifer is the impermeable quartzite and shale for- 
mations, whereas the top of the aquifer is the surface topography. The groundwater table is affected by seasonal and atmospheric variations. The aquifer is, therefore, regarded as semi-confined. The aquifer parameters, which include transmissivity and stativity, are considered to be low, and groundwater movement through this aquifer is, therefore, also slow [4]. The map above on Figure 1 is illustrating sampling sites of both the groundwater and the surface water that was sampled during the dry and the rainy season. The sampling sites are located mainly on the dolomitic rock which has a property of storing good quantities of water.

\section{Methodology}

The data compilation process incorporated a desktop study and site visits to collect groundwater and surface water samples for analysis at Waterlab, Pretoria. The study area is the Western Basin, within the Witwatersrand Basin, where there are mining activities, farming activities, a game reserve and some rural communities.

The study area was delineated utilising desktop resources such as maps (aerial photographs, geological maps, and land satellite maps) and water resource reports of the study area available, and the research incorporated the Department of Water and Sanitation's (DWS) water resource information database called the National Groundwater Archives (NGA), previously called the National Groundwater Database (NGDB) and Water Management System (WMS); both systems are licensed, operated and administrated by the DWS.

The fieldwork was conducted during the months August-September 2015 for the dry season water samples of both the groundwater and surface water at six monitoring sites. The rainy season water samples were collected in January 2016 for both the groundwater and surface water at six monitoring sites.

The groundwater and surface water in the study area was sampled using two distinct tools and techniques. Groundwater was sampled using a bailer. The surface water was sampled using the open water sample method in which an individual would get into the water and rinse the sampling bottle three times with a tributary's water, and then sample the water with the bottle mouth opposite the flow of the tributary while holding the sampling bottle under the water until the bottle is full and without aeration.

Results

The surface and groundwater Samples 1 - 6 were taken seasonally because it is important to assess the seasonal impact the effluent from the mining area has on the aquatic environment during the high flow and low flow of the river. The second reason is that this study will contribute to the limited data available in National Groundwater Archives (NGA) and Water Management System (WMS) programmes that are administered by the Department of Water and Sanitation, or at least show that there is a need to monitor ground water and surface water quality constantly in areas surrounding mines. This knowledge will contribute to the understanding of the geochemical dynamics of the aquatic environment in the Western Basin on the Witwatersrand Basin, and how the dolomitic aquifer specifically is affected by the gold mining activities in the study area.

The surface water and groundwater quality Samples 1 - 6 were analysed by the Waterlab in Pretoria, where the samples were analysed for environmental chemistry ( $\mathrm{pH}$ and sulphates) and metals (Al, As, B, Ba, Ca, Co, Fe, K, Li, Mg, Mn, Na, Ni, Rb, Si, Sr, Ti and Zn) using the inductively coupled plasma mass spectrometry (ICP-OES).

The surface and groundwater samples were analysed at Waterlab at a temperature of $25^{\circ} \mathrm{C}$. For both seasons, the $\mathrm{pH}$ values of some of the samples from Sites 1 - 6 conformed to the acceptable pH ranges of 6 - 8 as a determined requirement of DWAF [5], and others did not. The $\mathrm{pH}$ values of the surface water from Site 4 did not conform to DWAF's requirements. This was also the case for the $\mathrm{pH}$ values of the samples from Site 1 (groundwater) and Site 5 (surface water) on the rainy season, which indicate acid mine drainage (AMD). The $\mathrm{pH}$ values of the other samples fell within the range of $6-9$, meaning that they conformed to the requirements of DWAF [6].

The water quality results of the surface water and groundwater samples taken over the two seasons, dry and rainy seasons are extensively discussed on the Discussion and Conclusion of the research paper.

\section{Discussion}

The surface and groundwater samples were analysed at Waterlab at a temperature of $25^{\circ} \mathrm{C}$. For both seasons, the $\mathrm{pH}$ values of some of the samples from Sites 1 - 6 conformed to the acceptable pH ranges of 6 - 8 as a determined requirement of DWAF (1996), and others did not. The $\mathrm{pH}$ values of the surface water from Site 4 did not conform to DWAF's requirements. This was also the case for the $\mathrm{pH}$ values of the samples from Site 1 (groundwater) and Site 5 (surface water) on the rainy season, which indicate the presence of acid mine drainage (AMD). The $\mathrm{pH}$ values of the other samples fell within the range of $6-9$, meaning that they conformed to the requirements of DWAF (1996). The increase or decrease in the $\mathrm{pH}$ values outside of the 6 - 9 range has dire effects on the aquatic ecosystem, also attributes to the migration of species due to stresses brought about the aquatic environment by the $\mathrm{pH}$ [7]. It has also been documented in previous studies that the more far off the $\mathrm{pH}$ range (6 - 9) the higher the mortality rate for aquatic species and more species are affected by it $(\mathrm{pH})$ [7].

The $\mathrm{pH}$ values in the sampling sites $(1-6)$ also indicated evidence that there was also influence by metal concentration. The waste water treatment plant in the study area utilised by the mining company operating is utilising carbonate materials and limestone as means of buffering the $\mathrm{pH}$ in the TRB System. The concentration of metals like aluminium, cadmium, copper and lead in the water 


\begin{tabular}{|c|c|c|c|c|c|c|c|}
\hline \multicolumn{8}{|l|}{ Dry Season } \\
\hline \multirow{2}{*}{\begin{tabular}{|l|} 
Surface water \\
Sample site(s)
\end{tabular}} & \multicolumn{7}{|c|}{ Physico Parameters } \\
\hline & Site 1 & Site 2 & Site 3 & Site 4 & Site 5 & Site 6 & TWQR \\
\hline $\mathrm{pH}$ & 7.5 & 6.8 & 6.9 & 5.1 & 8.2 & 7.9 & 6-8 \\
\hline $\mathrm{SO}_{4}$ & 2480 & 2156 & 2064 & 2067 & 145 & 16 & $0-200$ \\
\hline \multicolumn{8}{|l|}{ Dry Season } \\
\hline Surface water & \multicolumn{7}{|c|}{ Metals } \\
\hline Sample site(s) & Site 1 & Site 2 & Site 3 & Site 4 & Site 5 & Site 6 & TWQR \\
\hline $\mathrm{Al}(\mathrm{mg} / \mathrm{L})$ & 0.222 & $<0.100$ & $<0.100$ & $<0.100$ & 0.253 & $<0.100$ & 0.005 \\
\hline $\mathrm{As}(\mathrm{mg} / \mathrm{L})$ & 0.016 & 0.044 & 0.013 & 0.019 & $<0.100$ & $<0.100$ & 0.01 \\
\hline $\mathrm{B}(\mathrm{mg} / \mathrm{L})$ & 0.048 & 0.026 & $<0.010$ & $<0.010$ & $<0.010$ & $<0.010$ & $\mathrm{~N} / \mathrm{A}$ \\
\hline $\mathrm{Ba}(\mathrm{mg} / \mathrm{L})$ & 0.011 & 0.010 & 0.007 & 0.007 & 0.008 & 0.007 & $\mathrm{~N} / \mathrm{A}$ \\
\hline $\mathrm{Ca}(\mathrm{mg} / \mathrm{L})$ & 791 & 568 & 504 & 497 & 73 & 16 & $\mathrm{~N} / \mathrm{A}$ \\
\hline $\mathrm{Co}(\mathrm{mg} / \mathrm{L})$ & 0.02 & 0.017 & $<0.010$ & $<0.010$ & $<0.010$ & $<0.010$ & N/A \\
\hline $\mathrm{Fe}(\mathrm{mg} / \mathrm{L})$ & 1.46 & 0.326 & 0.048 & 0.059 & 0.525 & $<0.025$ & 0.1 \\
\hline $\mathrm{K}(\mathrm{mg} / \mathrm{L})$ & 16.9 & 13.8 & 12.1 & 11.4 & 1.2 & 1.1 & 50 \\
\hline $\mathrm{Li}(\mathrm{mg} / \mathrm{L})$ & 0.048 & 0.028 & $<0.010$ & $<0.010$ & $<0.010$ & $<0.010$ & $\mathrm{~N} / \mathrm{A}$ \\
\hline $\operatorname{Mg}(\mathrm{mg} / \mathrm{L})$ & 149 & 138 & 104 & 132 & 40 & 15 & $\mathrm{~N} / \mathrm{A}$ \\
\hline $\mathrm{Mn}(\mathrm{mg} / \mathrm{L})$ & 5.86 & 8.14 & 5.82 & 6.78 & 0.688 & $<0.025$ & 0.18 \\
\hline $\mathrm{Na}(\mathrm{mg} / \mathrm{L})$ & 152 & 129 & 85 & 118 & 27 & 6 & $\mathrm{~N} / \mathrm{A}$ \\
\hline $\mathrm{Ni}(\mathrm{mg} / \mathrm{L})$ & 0.065 & 0.097 & 0.043 & 0.072 & 0.011 & $<0.010$ & N/A \\
\hline $\mathrm{Rb}(\mathrm{mg} / \mathrm{L})$ & 0.013 & 0.010 & $<0.010$ & $<0.010$ & $<0.010$ & $<0.010$ & N/A \\
\hline $\mathrm{Si}(\mathrm{mg} / \mathrm{L})$ & 1.6 & 2 & 2.3 & 1.7 & 6.3 & 5.3 & $\mathrm{~N} / \mathrm{A}$ \\
\hline $\mathrm{Sr}(\mathrm{mg} / \mathrm{L})$ & 0.353 & 0.266 & 0.159 & 0.154 & 0.017 & 0.017 & $\mathrm{~N} / \mathrm{A}$ \\
\hline $\mathrm{Ti}(\mathrm{mg} / \mathrm{L})$ & 0.81 & 0.502 & 0.212 & 0.181 & 0.059 & 0.011 & N/A \\
\hline $\mathrm{Zn}(\mathrm{mg} / \mathrm{L})$ & 0.016 & 0.011 & $<0.010$ & 0.011 & 0.019 & $<0.010$ & 0.02 \\
\hline
\end{tabular}

Table 1: Illustrating the $\mathrm{pH}$, sulphates and the metals of the surface water during the dry season (August 2015) from Sample Site 1-6 on the TRB System.

\begin{tabular}{|c|c|c|c|c|c|c|c|}
\hline \multicolumn{8}{|l|}{ Dry Season } \\
\hline \multirow{2}{*}{$\begin{array}{l}\text { Groundwater } \\
\text { Sample site(s) }\end{array}$} & \multicolumn{7}{|c|}{ Physico Parameters } \\
\hline & Site 1 & Site 2 & Site 3 & Site 4 & Site 5 & Site 6 & TWQR \\
\hline $\mathrm{pH}$ & 6.1 & 6.3 & 7 & 7.2 & 7.4 & 7.2 & $6-8$ \\
\hline $\mathrm{SO}_{4}$ & 2569 & 2156 & 7 & $<5$ & 553 & 224 & $0-200$ \\
\hline \multicolumn{8}{|l|}{ Dry Season } \\
\hline Groundwater & \multicolumn{7}{|c|}{ Metals } \\
\hline Sample site(s) & Site 1 & Site 2 & Site 3 & Site 4 & Site 5 & Site 6 & TWQR \\
\hline $\mathrm{Al}(\mathrm{mg} / \mathrm{L})$ & $<0.010$ & 0.104 & 0.121 & 0.106 & 0.188 & $<0.010$ & 0.005 \\
\hline $\mathrm{As}(\mathrm{mg} / \mathrm{L})$ & 0.333 & 0.046 & $<0.010$ & 0.013 & $<0.010$ & $<0.010$ & 0.01 \\
\hline $\mathrm{B}(\mathrm{mg} / \mathrm{L})$ & 0.052 & $<0.010$ & $<0.010$ & $<0.010$ & $<0.010$ & $<0.010$ & $\mathrm{~N} / \mathrm{A}$ \\
\hline $\mathrm{Ba}(\mathrm{mg} / \mathrm{L})$ & 0.024 & 0.012 & $<0.010$ & $<0.010$ & $<0.010$ & $<0.010$ & $\mathrm{~N} / \mathrm{A}$ \\
\hline $\mathrm{Ca}(\mathrm{mg} / \mathrm{L})$ & 600 & 501 & 32 & 155 & 23 & 72 & $\mathrm{~N} / \mathrm{A}$ \\
\hline $\mathrm{Co}(\mathrm{mg} / \mathrm{L})$ & 0.06 & $<0.010$ & $<0.010$ & $<0.010$ & $<0.010$ & $<0.010$ & $\mathrm{~N} / \mathrm{A}$ \\
\hline $\mathrm{Fe}(\mathrm{mg} / \mathrm{L})$ & 109 & 11 & 1.54 & 0.138 & 6.47 & $<0.025$ & 0.1 \\
\hline $\mathrm{K}(\mathrm{mg} / \mathrm{L})$ & 17 & 7.8 & 1.2 & 2 & 12.3 & 2.4 & 50 \\
\hline $\mathrm{Li}(\mathrm{mg} / \mathrm{L})$ & 0.041 & $<0.010$ & $<0.010$ & $<0.010$ & $<0.010$ & $<0.010$ & N/A \\
\hline $\mathrm{Mg}(\mathrm{mg} / \mathrm{L})$ & 142 & 106 & 24 & 66 & 10 & 40 & $\mathrm{~N} / \mathrm{A}$ \\
\hline $\mathrm{Mn}(\mathrm{mg} / \mathrm{L})$ & 36 & 15 & 0.217 & $<0.025$ & 0.492 & $<0.025$ & 0.18 \\
\hline $\mathrm{Na}(\mathrm{mg} / \mathrm{L})$ & 138 & 106 & $<2$ & 49 & 25 & 46 & $\mathrm{~N} / \mathrm{A}$ \\
\hline $\mathrm{Ni}(\mathrm{mg} / \mathrm{L})$ & 0.614 & 0.284 & 0.013 & 0.017 & 0.042 & 0.007 & $\mathrm{~N} / \mathrm{A}$ \\
\hline $\mathrm{Rb}(\mathrm{mg} / \mathrm{L})$ & 0.017 & 0.012 & $<0.010$ & $<0.010$ & 0.013 & $<0.010$ & $\mathrm{~N} / \mathrm{A}$ \\
\hline $\mathrm{Si}(\mathrm{mg} / \mathrm{L})$ & 8.6 & 7.8 & 3.9 & 7.8 & 1.3 & 5.8 & $\mathrm{~N} / \mathrm{A}$ \\
\hline $\mathrm{Sr}(\mathrm{mg} / \mathrm{L})$ & 0.409 & 0.258 & $<0.010$ & 0.046 & 0.015 & 0.026 & $\mathrm{~N} / \mathrm{A}$ \\
\hline $\mathrm{Ti}(\mathrm{mg} / \mathrm{L})$ & 0.712 & 0.364 & 0.022 & 0.091 & 0.014 & 0.041 & $\mathrm{~N} / \mathrm{A}$ \\
\hline $\mathrm{Zn}(\mathrm{mg} / \mathrm{L})$ & $<0.010$ & 0.312 & $<0.010$ & 0.115 & 0.011 & $<0.010$ & 0.02 \\
\hline
\end{tabular}

Table 2: Illustrating the $\mathrm{pH}$, sulphates and the metals of the groundwater during the dry season (September 2015) from Sample Site 1-6 on the TRB System. 


\begin{tabular}{|c|c|c|c|c|c|c|c|}
\hline \multicolumn{8}{|l|}{ Dry Season } \\
\hline \multirow{2}{*}{$\begin{array}{l}\text { Surface water } \\
\text { Sample site(s) }\end{array}$} & \multicolumn{7}{|c|}{ Physico Parameters } \\
\hline & Site 1 & Site 2 & Site 3 & Site 4 & Site 5 & Site 6 & TWQR \\
\hline $\mathrm{pH}$ & 7.3 & 7.3 & 7.2 & 5.3 & 5.6 & 6.5 & $6-8$ \\
\hline $\mathrm{SO}_{4}$ & 1902 & 1868 & 1787 & 1743 & 192 & 12 & $0-200$ \\
\hline \multicolumn{8}{|l|}{ Dry Season } \\
\hline Surface water & \multicolumn{7}{|c|}{ Metals } \\
\hline Sample site(s) & Site 1 & Site 2 & Site 3 & Site 4 & Site 5 & Site 6 & TWQR \\
\hline $\mathrm{Al}(\mathrm{mg} / \mathrm{L})$ & 0.151 & $<0.100$ & $<0.100$ & 0.015 & 0.164 & 0.496 & 0.005 \\
\hline $\mathrm{As}(\mathrm{mg} / \mathrm{L})$ & 0.087 & 0.093 & 0.087 & 0.089 & 0.025 & $<0.010$ & 0.01 \\
\hline $\mathrm{B}(\mathrm{mg} / \mathrm{L})$ & 0.063 & 0.048 & 0.049 & 0.051 & $<0.010$ & $<0.010$ & $\mathrm{~N} / \mathrm{A}$ \\
\hline $\mathrm{Ba}(\mathrm{mg} / \mathrm{L})$ & 0.03 & 0.02 & 0.018 & 0.019 & $<0.010$ & 0.015 & $\mathrm{~N} / \mathrm{A}$ \\
\hline $\mathrm{Ca}(\mathrm{mg} / \mathrm{L})$ & 559 & 534 & 516 & 524 & 89 & 17 & $\mathrm{~N} / \mathrm{A}$ \\
\hline $\mathrm{Co}(\mathrm{mg} / \mathrm{L})$ & 0.026 & 0.019 & 0.017 & 0.017 & $<0.010$ & $<0.010$ & N/A \\
\hline $\mathrm{Fe}(\mathrm{mg} / \mathrm{L})$ & 0.894 & 0.277 & 0.129 & 0.058 & 0.262 & 0.789 & 0.1 \\
\hline $\mathrm{K}(\mathrm{mg} / \mathrm{L})$ & 14.9 & 11.4 & 10.4 & 10.4 & 0.5 & 2.1 & 50 \\
\hline $\mathrm{Li}(\mathrm{mg} / \mathrm{L})$ & 0.064 & 0.046 & 0.037 & 0.041 & 0.011 & $<0.010$ & N/A \\
\hline $\operatorname{Mg}(\mathrm{mg} / \mathrm{L})$ & 105 & 81 & 76 & 71 & 48 & 12 & $\mathrm{~N} / \mathrm{A}$ \\
\hline $\mathrm{Mn}(\mathrm{mg} / \mathrm{L})$ & 5.74 & 1.74 & 1.68 & 1.84 & 0.15 & 0.043 & 0.18 \\
\hline $\mathrm{Na}(\mathrm{mg} / \mathrm{L})$ & 222 & 135 & 108 & 112 & 38 & 11 & $\mathrm{~N} / \mathrm{A}$ \\
\hline $\mathrm{Ni}(\mathrm{mg} / \mathrm{L})$ & 0.104 & 0.07 & 0.068 & 0.07 & 0.01 & $<0.010$ & $\mathrm{~N} / \mathrm{A}$ \\
\hline $\mathrm{Rb}(\mathrm{mg} / \mathrm{L})$ & 0.015 & 0.013 & 0.011 & 0.012 & $<0.010$ & $<0.010$ & $\mathrm{~N} / \mathrm{A}$ \\
\hline $\mathrm{Si}(\mathrm{mg} / \mathrm{L})$ & 27 & 9.2 & 5.3 & 3.7 & 7.5 & 6.1 & $\mathrm{~N} / \mathrm{A}$ \\
\hline $\mathrm{Sr}(\mathrm{mg} / \mathrm{L})$ & 0.365 & 0.333 & 0.308 & 0.316 & 0.038 & 0.028 & $\mathrm{~N} / \mathrm{A}$ \\
\hline $\mathrm{Ti}(\mathrm{mg} / \mathrm{L})$ & 0.768 & 0.811 & 0.755 & 0.773 & 0.112 & 0.02 & $\mathrm{~N} / \mathrm{A}$ \\
\hline $\mathrm{Zn}(\mathrm{mg} / \mathrm{L})$ & 0.042 & 0.02 & 0.031 & 0.029 & 0.023 & 0.011 & 0.02 \\
\hline
\end{tabular}

Table 3: Illustrating the $\mathrm{pH}$, sulphates and the metals of the surface water during the rainy season (January 2016) from Sample Site 1-6 on the TRB System.

\begin{tabular}{|c|c|c|c|c|c|c|c|}
\hline \multicolumn{8}{|l|}{ Rainy Season } \\
\hline \multirow{2}{*}{\begin{tabular}{|l|} 
Groundwater \\
Sample site(s) \\
\end{tabular}} & \multicolumn{7}{|c|}{ Physico Parameters } \\
\hline & Site 1 & Site 2 & Site 3 & Site 4 & Site 5 & Site 6 & TWQR \\
\hline $\mathrm{pH}$ & 5.8 & 6 & 7.2 & 7 & 7.3 & 7 & $6-8$ \\
\hline $\mathrm{SO}_{4}$ & 2605 & 1777 & 6 & 579 & 2 & 226 & $0-200$ \\
\hline \multicolumn{8}{|l|}{ Rainy Season } \\
\hline Groundwater & \multicolumn{7}{|c|}{ Metals } \\
\hline Sample site(s) & Site 1 & Site 2 & Site 3 & Site 4 & Site 5 & Site 6 & TWQR \\
\hline $\mathrm{Al}(\mathrm{mg} / \mathrm{L})$ & $<0.010$ & $<0.010$ & $<0.010$ & $<0.010$ & 0.013 & $<0.010$ & 0.005 \\
\hline $\mathrm{As}(\mathrm{mg} / \mathrm{L})$ & 0.126 & 0.087 & $<0.010$ & 0.031 & $<0.010$ & 0.015 & 0.01 \\
\hline $\mathrm{B}(\mathrm{mg} / \mathrm{L})$ & 0.093 & 0.058 & $<0.010$ & $<0.010$ & $<0.010$ & $<0.010$ & $\mathrm{~N} / \mathrm{A}$ \\
\hline $\mathrm{Ba}(\mathrm{mg} / \mathrm{L})$ & 0.021 & $<0.010$ & $<0.010$ & $<0.010$ & $<0.010$ & $<0.010$ & $\mathrm{~N} / \mathrm{A}$ \\
\hline $\mathrm{Ca}(\mathrm{mg} / \mathrm{L})$ & 625 & 485 & 40 & 166 & 27 & 82 & $\mathrm{~N} / \mathrm{A}$ \\
\hline $\mathrm{Co}(\mathrm{mg} / \mathrm{L})$ & 0.042 & $<0.010$ & $<0.010$ & $<0.010$ & $<0.010$ & $<0.010$ & $\mathrm{~N} / \mathrm{A}$ \\
\hline $\mathrm{Fe}(\mathrm{mg} / \mathrm{L})$ & 34 & 16 & 1.35 & 0.074 & 4.79 & 0.039 & 0.1 \\
\hline $\mathrm{K}(\mathrm{mg} / \mathrm{L})$ & 17.5 & 11.5 & 0.8 & 1 & 9.6 & 1.9 & 50 \\
\hline $\mathrm{Li}(\mathrm{mg} / \mathrm{L})$ & 0.066 & 0.038 & $<0.010$ & $<0.010$ & $<0.010$ & $<0.010$ & $\mathrm{~N} / \mathrm{A}$ \\
\hline $\operatorname{Mg}(\mathrm{mg} / \mathrm{L})$ & 154 & 91 & 29 & 71 & 11 & 43 & $\mathrm{~N} / \mathrm{A}$ \\
\hline $\mathrm{Mn}(\mathrm{mg} / \mathrm{L})$ & 29 & 5.59 & 0.185 & $<0.025$ & 0.398 & $<0.025$ & 0.18 \\
\hline $\mathrm{Na}(\mathrm{mg} / \mathrm{L})$ & 162 & 128 & 4 & 52 & 25 & 52 & $\mathrm{~N} / \mathrm{A}$ \\
\hline $\mathrm{Ni}(\mathrm{mg} / \mathrm{L})$ & 0.259 & 0.161 & 0.012 & 0.012 & 0.036 & $<0.010$ & $\mathrm{~N} / \mathrm{A}$ \\
\hline $\mathrm{Rb}(\mathrm{mg} / \mathrm{L})$ & 0.017 & 0.027 & 0.003 & 0.005 & 0.018 & 0.006 & $\mathrm{~N} / \mathrm{A}$ \\
\hline $\mathrm{Si}(\mathrm{mg} / \mathrm{L})$ & 7.6 & 1.5 & 3.9 & 8.7 & 1.5 & 5.7 & $\mathrm{~N} / \mathrm{A}$ \\
\hline $\operatorname{Sr}(\mathrm{mg} / \mathrm{L})$ & 0.438 & 0.346 & 0.017 & 0.088 & 0.028 & 0.059 & $\mathrm{~N} / \mathrm{A}$ \\
\hline $\mathrm{Ti}(\mathrm{mg} / \mathrm{L})$ & 0.94 & 0.736 & 0.062 & 0.253 & 0.04 & 0.12 & $\mathrm{~N} / \mathrm{A}$ \\
\hline $\mathrm{Zn}(\mathrm{mg} / \mathrm{L})$ & $<0.010$ & 0.156 & 0.016 & 0.4 & 0.025 & 0.021 & 0.02 \\
\hline
\end{tabular}

Table 4: Illustrating the $\mathrm{pH}$, sulphates and the metals of the groundwater during the rainy season (January 2016) from Sample Sites 1-6 on the TRB System. 
body increase when the $\mathrm{pH}$ value is low instead of being absorbed by the sediment in the TRB System [7].

The sulphate concentration in the surface water had a linear decrease in seasons, as seen decreasing from Site 1 - 4 (dry season, $2067 \mathrm{mg} / \mathrm{L}$ and rainy season, $1743 \mathrm{mg} / \mathrm{L}$ ), and drastically dropping from Site 5 (dry season, $145 \mathrm{mg} / \mathrm{L}$ and rainy season, 192 $\mathrm{mg} / \mathrm{L}$ ) to Site 6 (dry season, $16 \mathrm{mg} / \mathrm{L}$ and rainy season, $12 \mathrm{mg} / \mathrm{L}$ ). The sulphate content in the groundwater samples in both seasons followed a similar trend from Sites 1 - 2, but seemed to differ for the two seasons: starting from Sites 1 - 2 (dry season, $2156 \mathrm{mg} / \mathrm{L}$ and rainy season, $1777 \mathrm{mg} / \mathrm{L}$ ), followed by a drastic drop at Site 3. For Site 4 , the sulphate content differs in the two seasons, as it drops further in the dry season $(<5 \mathrm{mg} / \mathrm{L})$, whereas it increases drastically in the rainy season $(579 \mathrm{mg} / \mathrm{L})$. This followed by a spike at Site 5 in the dry season (553 $\mathrm{mg} / \mathrm{L})$ and a drastic drop in the rainy season $(2 \mathrm{mg} / \mathrm{L})$. The sulphate content at Site 6 in the dry season drops significantly when compared to that at Site 5 (from $553 \mathrm{mg} / \mathrm{L}$ to $224 \mathrm{mg} / \mathrm{L}$ ), but there is drastic increase when the two sites are compared in the rainy season (from $2 \mathrm{mg} / \mathrm{L}$ at Site 5 to $226 \mathrm{mg} / \mathrm{L}$ at Site 6).

The high concentration of sulphate on the TRB system and gradual decrease in concentration is indicative of point source pollution that is related to mining activities in the study area. The sulphate concentration from sample Site 1 - 6 in the TRB System is indicative AMD through pyrite oxidation processes. The presence of sulphate in the aquatic environment is important for plants but in moderate concentrations of $0-200 \mathrm{mg} / \mathrm{L}$ [7].

During the dry season (August 2015) the surface water metal concentrations were as follows; Aluminium concentrations at Sites 1 and 5 exceeded the TWQR and Sites $2-4$ and 6 were below the detection limit. Aluminium is highly toxic to aquatic ecosystems and is indicative of Acid Mine Drainage (AMD) impacted waters (DWAF, 1996). Arsenic concentrations at Sites 1 - 4 and exceeded the TWQR and at Sites 5 and 6 were below the detection limit. The presence of arsenic is more related to industrial pollution than natural occurrence (DWAF, 1996). Iron concentrations at Sites 1, 2 and 5 exceeded the TWQR. The presence of iron is indicative of AMD from the geochemical reaction of oxidation of pyrite. Manganese concentrations at Sites 1 - 5 exceeded the TWQR and Site 6 was below the detection limit. Manganese linear decline in quantity concentration is indicative of AMD from the mining activities in the Witwatersrand Basin, Western Basin.

During the dry season the (September 2015) the groundwater metal concentration was as follows; Aluminium concentrations at sites 2 - 5 exceeded the TWQR and Sites 1 and 6 were below the detection limit. The high concentration of aluminium in the study area is indicative of industrial pollution (DWAF, 1996). Arsenic concentrations at Sites 1, 2 and 4 exceeded the TWQR and Sites 3 4 and 6 were below the detection limit. Iron concentrations at Sites 1 - 5 exceeded the TWQR and Site 6 was below the detection limit.
Manganese concentrations at Sites 1 - 3 and 5 exceeded the TWQR and Sites 4 and 6 were below the detection limit. Zinc concentrations at Site 2 exceeded the TWQR and Sites 1, 3 and 6 were below the detection limit. Zinc is introduced to aquatic ecosystems by leaching of ores containing it and through mining activities (DWAF, 1996).

During the rainy season (January 2016) the surface water metal concentration was as follows; Aluminium concentrations at Sites 1 and $4-6$ exceeded the TWQR and Sites 2 and 3 were below the detection limit. Arsenic concentrations at Sites $1-5$ exceeded the TWQR and Site 6 was below the detection limit. Iron concentrations at Sites 1 - 6 exceeded the TWQR. Manganese concentrations at Sites 1 - 4 exceeded the TWQR. Zinc concentrations at Sites 1 - 5 exceed the TWQR. The linear decline in the concentration of aluminium, arsenic, iron and manganese is indicative of AMD.

During the rainy season (January 2016) the groundwater metal concentration was as follows; Aluminium concentrations at Site 5 exceeded the TWQR and Sites $1-4$ and 6 were below the detection limit. Arsenic concentrations at Sites 1 - 4 and 6 exceeded the TWQR and Sites 3 and 5 were below the detection limit. Iron concentrations at Sites $1-3$ and 5 exceeded the TWQR. Manganese concentrations at Sites $1-3$ and 5 exceeded the TWQR and Sites 4 and 6 were below the detection limit. Zinc concentrations at Sites 2 and 4 - 6 exceeded the TWQR and Site 1 was below the detection limit. The presence of zinc in the study area may be indicative of AMD [8].

\section{Conclusion}

The most prevalent form of pollution to the water resource in the Western Basin, within the Witwatersrand Basin, is the effluent that decants from the defunct mine voids in the area. When most mining companies ceased their operations in 2000, the abundant mine shafts started to flood. In 2002, the mine shafts started to decant from the West Rand Mine Basin (WRB) into TRB System. The Department of Water and Sanitation (DWS), as the custodian of water resources in the country, ordered the mines operating in the area to pre-treat the decant water. The mines treated the decant water through a process of lime addition and aeration, and a secondary treatment called the wetland system.

The best way the AMD problem can be remedied is through oxidation reactions that form oxides and hydroxides within the aerobic cell in the wetland. The wetlands are known for their ability to reduce nitrate and heavy metal concentrations in a water body. Alternative remediation methods for the effects of AMD were identified and analysed in the study area, and all solutions came down to constructed wetlands. This is not a straightforward solution; however, a specific scientifically engineered wetland to accommodate all the different pollutants and water quality levels needs to be constructed and managed properly [9]. 


\section{Bibliography}

1. Chennakrishnan C., et al. Water Quality status of three vulnerable freshwater Lakes of Suburban Chennai, India (2008).

2. Mathuthu AS., et al. Impact Assessment of Industrial and Sewage Effluents on Water Quality of receiving Marimba River in Harare (1997).

3. Midgley DC., et al. Surface water resources of South Africa, Limpopo-Olifants (Appendices) book of maps, WRC Report 1 (1994).

4. Brink ABA. Engineering geology of Southern Africa, The first 2000 million years of geological time. Pretoria: Building Publications 1 (1979): 22-45.

5. Department of Water Affairs and Forestry South African Water Quality Guidelines (2nd Edition) Aquatic Ecosystems 55.7 (1996): 128.

6. DWAF (Department of Water Affairs and Forestry) South African Water Quality Guidelines Aquatic Ecosystems, (ed) S Holmes, 2nd edition. Department of Water Affairs and Forestry, Pretoria 7 (1996).

7. Hedin RS., et al. "Passive treatment of Acid Mine Drainage with limestone". Journal of Environmental Quality 23 (1994): 13381345.

8. Durand JF. Challenges associated with living in karst environments such as the historical Cradle of Humankind New Contree 54 (2007): 75-98.

9. Department of Water Affairs (2010).

\section{Volume 3 Issue 10 October 2019}

(C) All rights are reserved by Khanyiso Nkumanda. 